\title{
Constructing Agro-Industrial Clusters or Disembedding of the Territory? Lessons from Sinaloa as the Leading Horticultural Export-Oriented Region of Mexico
}

\author{
Carlos J. Maya-Ambía*
}

Faculty of Economic and Social Sciences, Universidad Autónoma de Sinaloa, México

\begin{abstract}
The long-term growth of horticultural exports from Sinaloa, Mexico, mainly to the United States, as well as the region's ranking as the most important area in Mexico in the production of fresh vegetables for foreign markets, leads us to question the regional impact of horticulture. Various methods can be used to perform such an assessment. One method examines the level of development of an agro-industrial cluster centered on horticultural production for export. Several cases in other regions show that clusters usually become powerful engines for the development of those regions, particularly those deeply embedded in the current economic globalization.
\end{abstract}

The aim of this paper is an assessment of Sinaloa's experience to investigate whether an agro-industrial cluster centered on export-oriented horticulture exists, and if one exists, how developed the cluster is. Therefore, for the Sinaloa case, each component of a cluster is analyzed, according to the literature on this topic.

The outcomes of this research show that although some attempts have been made to create a cluster, those attempts failed, and the cluster is incomplete and stagnant. Therefore I call Sinaloa a disembedded territory.

Keywords: Agroindustry, cluster, Mexico, Sinaloa.

\section{INTRODUCTION}

Some regions in the world have specialized in producing merchandise, for domestic or foreign markets. Based on this specialization, these regions have developed clusters, namely, new enterprises that complement the original group of enterprises, such as suppliers. The outcome has been regional development.

Within the context of neoliberal globalization, specialization in exported goods has been considered advantageous, particularly since the mid-'80s. A rich entrepreneurial web that combines supplemental economic activities with export activities leads to successful involvement in global markets, which is the key to promoting regional development. In a word, clusters emerge due to the strong orientation of the region toward foreign markets.

Sinaloa is clearly within the United States' sphere of influence. This region has been historically linked to the American economy, decades before the word globalization was in vogue, because Sinaloa channeled strong flows of goods to the United States before the idea that developing countries should become suppliers of agricultural high-value goods, such as vegetables, fruits and flowers, became fashionable [1].

Sinaloa is still the most important horticultural region of Mexico, particularly concerning horticultural exports. The

*Address correspondence to this author at the Faculty of Economic and Social Sciences. Universidad Autónoma de Sinaloa, México;

Tel: +52-667-7161341; Fax: +52-667-7161341;

E-mail: maya@uas.uasnet.mx region accounted for $27.1 \%$ of the domestic production of tomatoes, the leading exported vegetable, in 2007. In the realm of fruits, Sinaloa is also a significant player. For instance, Sinaloa produced $13.8 \%$ of the total production value of the country's mangos [2].

Sinaloa has been a significant player in domestic agricultural production since the XIX Century. The first product was sugar cane, then fresh vegetables, and now a days it is also a leading producer of maize. However, Sinaloa's economy is rich but unbalanced. The region is dominated by the primary sector, and has a hypertrophied services sector. This situation is partly due to the traditional success of the primary sector. At the same time, it has been evident the fragility of its process of modernization, due mainly to the fact that they have been based on the plundering of natural resources, particularly water, neglecting the sustainability of the economy. This process has also ignored managerial issues that could promote competitiveness based on durable fundamentals. A comparison of the gross domestic products (GDPs) of all the federal states of Mexico, from 1993 to 2004, shows that Sinaloa is one of eight states with lower rates of growth, namely, below $2 \%$. The rates of the states with the highest growth were above 4\%. ([3] p. 59-60).

Due to this slow growth, Sinaloa's share of the national GDP decreased, from $2.16 \%$ in 1993 to $1.89 \%$ in 2006. Therefore, the foundations of Sinaloa's economy are far from stable, and even worse, the region's long-term performance is negative. Consequently, investigating the relationship between the phenomena previously described and the presence or absence of an agro-industrial cluster in Sinaloa, built on export-oriented horticulture, is important. 


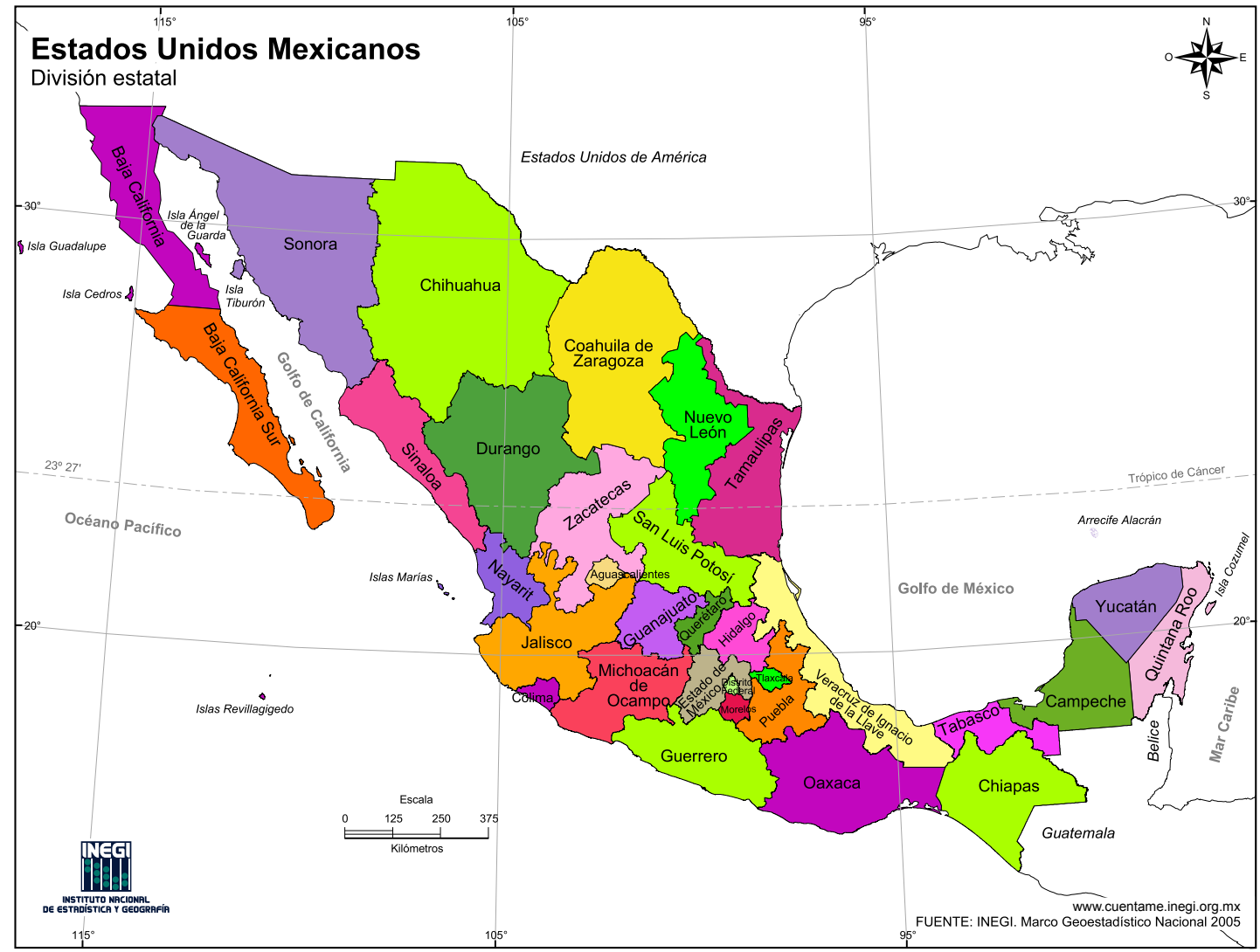

Fig. (1). Map of Mexico. Source: National Institute of Statistics and Geography (INEGI).

From 1993 to 2006, the growth rate of Sinaloa's agricultural sector was $1.8 \%$, while the national rate was $1.9 \%$. Despite Sinaloa's leading role in domestic agricultural production, the region's growth rate is below the national average; Sinaloa's more dynamic products could not compensate for the loss of earnings due to the low real prices caused by the opening up of trade barriers. In addition, traditional agricultural exports, basically fresh vegetables, did not get better access to foreign markets [4]. Mexico's horticultural exports increased 188\% from 1992 to 2007, but Sinaloa's exports grew just $13 \%$. Therefore, Sinaloa's share of Mexican horticultural exports decreased from $41.1 \%$ in $1992-93$ to $16.1 \%$ in $2007-08$ ([5] p. 58-59).

Therefore, the performance of Sinaloa's agricultural sector has not matched expectations, considering the region's significant agricultural resources. However, this sector's performance was comparatively better than Sinaloa's industrial and services sectors; the average annual rates were $0.9 \%$ and $2.2 \%$, respectively. Both were lower than the national figures, which were $3 \%$ and $3.1 \%$, respectively.

\section{THE RESEARCH PROBLEM}

The advantages of the concentration of firms in the same industry in a given territory were identified by Marshall as agglomeration economies. He pointed out three: a) a shared market of skilled labor force, b) the provision of cheap inputs, as suppliers seek to locate near their customers, and c) a technological osmosis, which consists of the transfer of technological advances among local firms. Many authors have enriched Marshall's original ideas and currently the cluster concept has become one of the most widely used by economists.

The OECD (Organisation for Economic Co-operation and Development) summarized the main points of the discussion in the last few years about clusters as follows:

"Economists have long noted that specific places specialize in particular activities and that firms engaged in the same or related activities tend to cluster together increasing productivity. While some definitions of clusters lack a spatial dimension, most definitions support the idea that a cluster includes firms and other knowledge-producing agents in a geographically concentrated area with interlinkages among them. A number of other terms are used by academics and policy makers to describe related phenomena, such as industrial districts, networking, systems of production or, for the broader environment, a regional innovation system" ([6] p.2) ${ }^{1}$.

\footnotetext{
${ }^{1}$ Many other authors express the same point of view, as can be seen in the following two quotations: "Clusters are groups of companies and institutions co-located in a specific geographic region and linked by interdependencies in providing a related group of products and/or services" ([7] p. 3-4). "The concept of clusters refers to the geographical concentration of interlinking businesses and institutions.(...) The idea is that if a group of businesses concentrates on the same economic activity in one region, covering several municipalities, consolidating this social and productive network and strengthening it to develop a suitable economy of scale will reduce costs, increase competitiveness and improve exports ([8] $\mathrm{p}$. $7-8)$.
} 
Cluster has two meanings: it is a category for describing a situation and a tool for promoting regional development. In the first sense, the term refers to the geographic concentration of a group of interlinked companies and institutions located in a particular territory. In the second sense, cluster has been used as a development strategy to promote innovation and coordination of production activities of economic agents located in a certain territory, to successfully confront the challenges of economic globalization. Accordingly, the cluster concept has become synonymous with "district" (industrial or agro-industrial district, network, or even regional system of innovation) [9].

Subsequently, authors introduced the concept of cluster into the realm of agriculture, since the creation of agricultural clusters would benefit regional development.

The OECD [9] believes that clusters provide a favorable environment for generating, applying, and disseminating innovations in production, which, in turn, boosts competitiveness and economic development.

However, Sinaloa's economy and the region's horticultural exports in particular show that, during the trade liberalization period, Sinaloa's economic development was below the national average and the competitiveness of the main exported products decreased.

These phenomena lead us to the following consideration. The main exporters of fresh vegetables from Mexico, not only from Sinaloa, are concentrated in a relatively small area. If Sinaloa's economy has performed so badly in recent years, we must ask whether this phenomenon is related to the insufficient development of a cluster centered on exported horticulture.

\section{METHODOLOGY}

To answer the research question, I will proceed as follows. First, I analyze Sinaloa's general economic situation and then focus on each component of an agro-industrial cluster to understand the specific characteristics in Sinaloa. The second step involves analytical interpretation of the research outcomes. Third, I explain the causes of the incomplete and stagnant cluster. Then I identify the limitations of the concept of cluster for an accurate understanding of the dynamics of a territory in the current globalized world, and therefore to recognize the necessity of widening our theoretical framework, including what Messner [10] has called the world economic triangle. Finally, the present research is significantly based on previous studies, by the author as well as other scholars interested in single aspects of a cluster, and on interviews, surveys, and personal opinions of specialists. This method was necessary because there is a significant lack of official statistical data for Sinaloa. $^{2}$

\section{SINALOA'S ECONOMY}

Sinaloa has been connected to global markets for several centuries. During the colonial period, Sinaloa exported mining, and in the 19th century, cotton, chickpea, and sugar cane were important exports for Sinaloa. At the beginning of

${ }^{2}$ For other Mexican states, several Input-Output Tables, including recent years, are available, but on the contrary, the most recent of these tables for Sinaloa corresponds to the ' 60 s. the 20th century, tomatoes were cultivated for export to the United States. Since then, Sinaloa's economy has been strongly linked to the American economy [4]. Later, the construction of dams in Mexico, to boost crop irrigation, particularly benefited Sinaloa; now there are 11 dams, powered by the same number of rivers, in the state. However, the Sierra Madre Occidental mountains isolate the area from the eastern part of the country and the southwest of the United States (see Fig. 2), due to the lack of efficient highways and railways to transport people and goods. These facts limit the possibility of taking advantage of Sinaloa's low costs and ports. In addition, Sinaloa has a low demographic concentration and is too far from large consumption centers. At the same time, Sinaloa's agricultural and fish products compete with those of neighboring states (see Fig. 1).

Sinaloa accounts for $2.9 \%$ of the nation's territory, and the region's 2.6 million inhabitants, represent, according to the latest population census (2005), $2.5 \%$ of the Mexican population. This figure is even lower than that of 2000 , which was $2.7 \%$ [11]. Furthermore, Sinaloa's population growth rate, $0.49 \%$, for $2000-2005$, was among the lowest in Mexico; the average rate was $1 \%$ for the same period. Accordingly, Sinaloa's population is expected begin to decrease in 2017 , due to emigration and a decreasing birth rate.

Although Sinaloa's per-capita income in 2006 was below the national average, the per-capita income of Baja California, Baja California Sur, and Sonora exceeded the national average by $30 \%, 24 \%$, and $23 \%$, respectively (see Fig. 1). Therefore, the accelerated migration from Sinaloa to these areas and to the United States in general is not surprising. To a large extent, the accelerated migration is linked to the agriculture crisis and to the fact that many small farmers, particularly ejidatarios, ${ }^{3}$ are unable to farm their land directly. A significant number have no access to credit, at a moment when guaranteed prices and sales, formerly secured by the Mexican government through Conasupo, ${ }^{4}$ completely disappeared. Thus, the farmers had to bear the costs of marketing. Moreover, the agriculture crisis gave way to a greater involvement of rural people in drug trafficking and other criminal activities and provoked increased migration.

Sinaloa's economic structure presents the following features. From 1993 to 2006, the area's share of agriculture of the state's GDP declined from $21.5 \%$ to $12 \%$, although

\footnotetext{
${ }^{3}$ Ejidatario is a farmer member of an ejido. The ejido system was a process whereby the government promoted the use of communal land shared by the people of the community. This use of community land was a common practice in the ancient Mexico, but the president Lázaro Cárdenas (19341940) introduced the ejido system as an important component of his land reform program. Some decades later, president Carlos Salinas de Gortari in 1991 modified the Mexican Constitution and the ejidos were eliminated. Since then some of the ejido land has been sold to corporations, although most of it is still in the hands of farmers.

${ }^{4}$ The National Company of Popular Subsistence (CONASUPO) was a state owned company, whose function was to control the supply system and food security in Mexico. It was created in 1962 to ensure the purchase and price regulation of basic products, particularly corn. Up until the 1990s, the government encouraged the production of basic crops (mainly corn and beans) by maintaining support prices and controlling imports through CONASUPO. With trade liberalization, however, CONASUPO was gradually dismantled.
} 


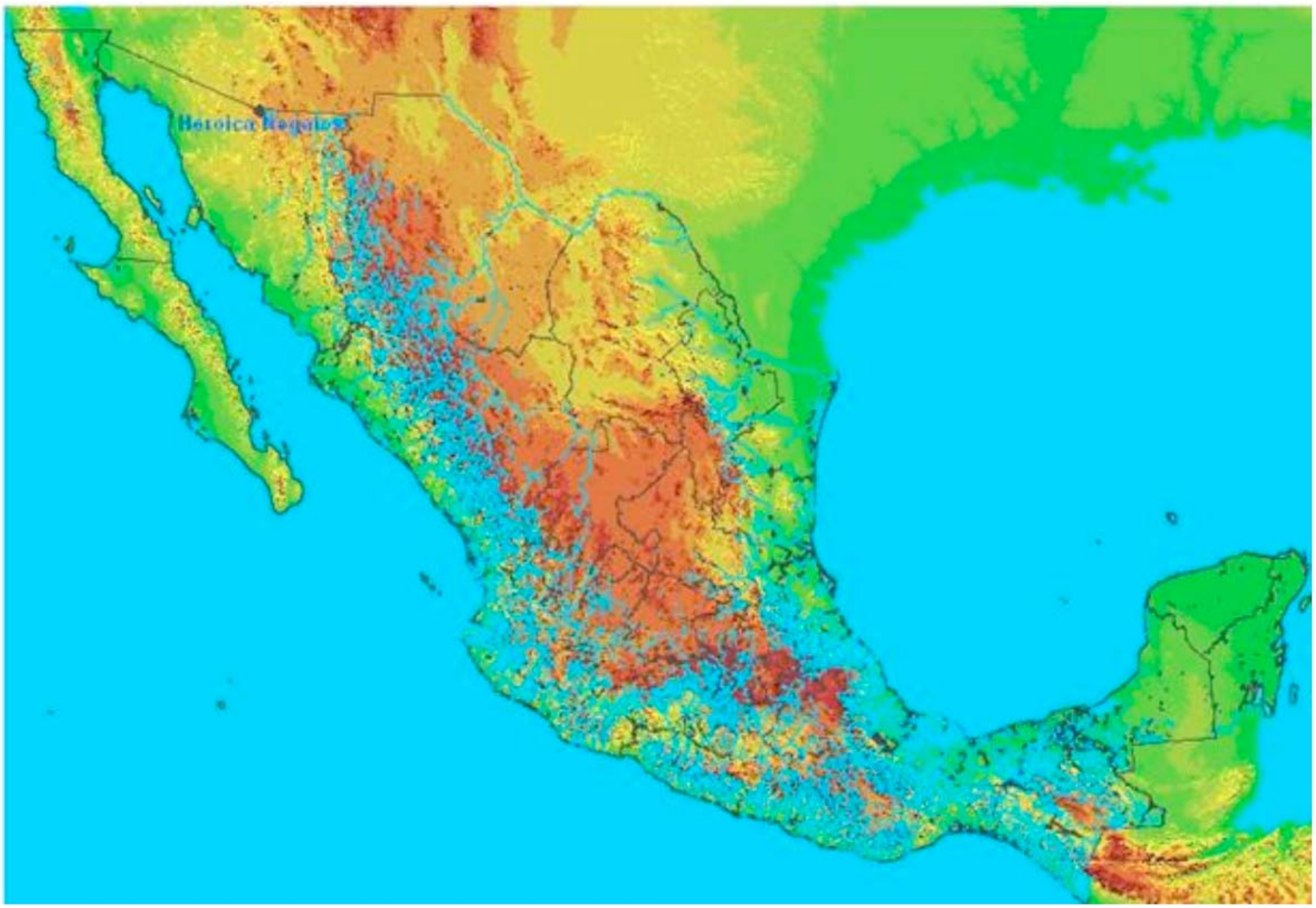

Fig. (2). Orographic and Hydrographic Map of Mexico. Source: National Institute of Statistics and Geography (INEGI).

the figure of Sinaloa's last official statistical yearbook is $13.4 \%$. On the other hand, the figures for the industrial sector are a modest $13.2 \%$ for 1993 and an even smaller $12.5 \%$ in 2006 . In contrast, the heterogeneous services sector expanded from $65 \%$ to $75.5 \%$ during the same period [12].

Particularly in the national agricultural sector, Sinaloa accounts for the largest percentage, with $9 \%$ of the value of domestic agricultural production from 2005 to 2007, followed closely by Michoacán (8.8\%), Jalisco (7.6\%), and Veracruz $(7.4 \%) .{ }^{5}$ On the other hand, Sinaloa's relatively large share of national agricultural production does not correspond to a large share of the national food industry, which usually is located close to the largest demographic centers. In Sinaloa, more than $70 \%$ of the manufacturing industry is involved in the food industry. However, this industry's portion of the national food industry is very small. Therefore, in the national ranking, Sinaloa is $12^{\text {th }}$ out of 32 federal states, and its share is just $2.2 \%$. The most important states are Distrito Federal (14.6\%), the State of Mexico (13.6\%), Jalisco (12.7\%), and Nuevo León (7.0\%).

Although the multiplier effect of agricultural activities must be taken into account, since most of the industrial and service activities in the state are closely related to agricultural supply and demand, the evolution depends on this sector's performance. We should also consider that, to a certain extent, this relationship explains the poor economic performance of the industrial and service sectors. They have been unable to create sustained dynamics of their own, independent of agriculture. In addition, neither the industrial sector nor the services sector has diversified to support agriculture [33].

The working population in the primary sector (agriculture) accounts for $21.1 \%$ of the total working population. In manufacturing, the working population is only $9.9 \%$ of the total working population. The trade and commerce working population is $20.6 \%$ of the total, and the working population of the other services (restaurants, lodging, professional services, financial and corporate, and miscellaneous services) sector is $29.3 \%$ of the total [12].

The agricultural area in Sinaloa is distributed among six districts. The largest is Los Mochis, with 345,000 hectares, followed by Culiacan (334,000 hectares), Guasave $(270,000$ hectares), Guamuchil (194,000 hectares), La Cruz (190,000 hectares), and Mazatlan (154,000 hectares) (Aguilar, 2007) (see Fig. 3). Thus, agricultural activity is located mostly in the center of the state, where there are wider valleys. Most of the grain crops are located in this area. The south is more suitable for fruits, and fresh vegetables are cultivated in all regions, particularly in the Valley of Culiacan, where the largest grower-exporters are located (see Fig. 4).

${ }^{5}$ See Fig. (1) for the location of the Mexican federal states. 


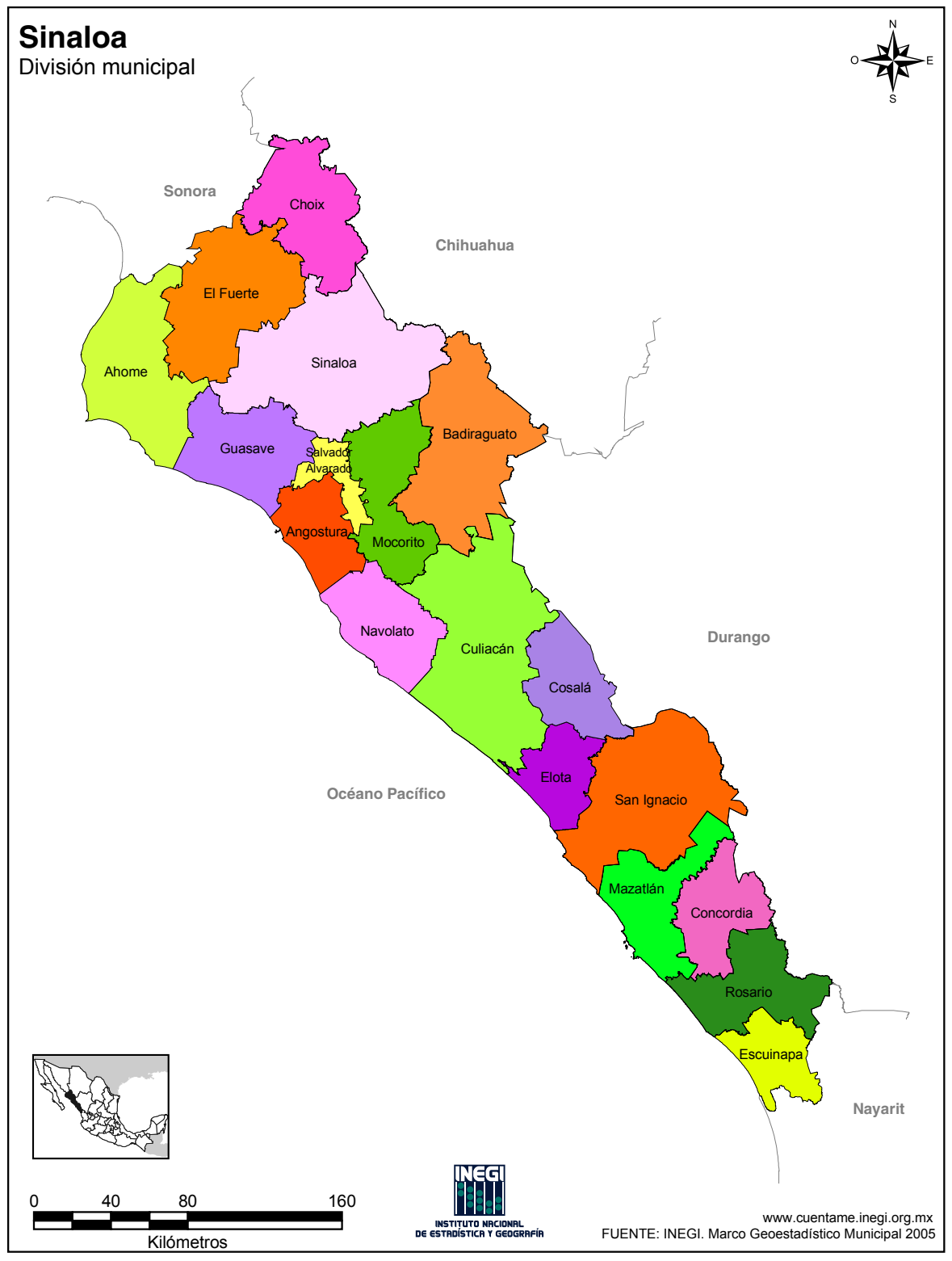

Fig. (3). Map of Sinaloa. Source: National Institute of Statistics and Geography (INEGI).

With respect to agricultural production in 2008 , maize accounted for $46.2 \%$ of the value, potatoes $4.9 \%$, beans $5.1 \%$, green chilies $8.5 \%$, red tomatoes $12.7 \%$, and other crops $22.6 \%$. Horticultural and fruit production for export is concentrated in the following municipalities: Guasave, Elota, Navolato, Mocorito, Culiacan, Escuinapa, Rosario, Ahome, El Fuerte, and Angostura [12] (see Fig. 3).

In 1995, there were 146,000 farmers in Sinaloa, and by 2006 , the number had increased to 152,000 . During the same period, the crop area increased from 1.429 million hectares to 1.487 million. Therefore, the average crop area per farmer did not change. It continued to be 9.8 hectares. At the same time, the average area was 18.6 hectares for private property and 8.3 hectares for social property (ejidos). Finally, the irrigated areas tend to increase [13].

In Sinaloa, the combination of mountains near relatively flat coastal areas situated in an area susceptible to hurricanes, with short but intense rains in the summer and an annual rainfall of 600 to $800 \mathrm{~mm}$, made the construction of large dams necessary for irrigation farming (see Fig. 2). The water is captured by dams in summer for use in autumn and winter and sometimes in the spring and summer. The weather conditions in autumn and winter are relatively mild, and neither frost nor heavy rain is frequent. These conditions give Sinaloa advantages in producing winter vegetables: Sinaloa is the leading exporter in Mexico of fresh vegetables. The main market is the United States, and Canada provides a smaller market. As Sinaloa's horticultural production is concentrated on an autumn and winter cycle, the region competes with Florida, the leading U.S. supplier at that time of year. This rivalry has led to farmers in Sinaloa to continually strive to improve the competitiveness of their produce. 
This is the background for our inquiry into the existence of an agro-industrial cluster centered on export horticulture in Sinaloa.

\section{STRUCTURE OF AN AGRO-INDUSTRIAL CLUSTER}

An agro-industrial cluster must have the following eight components: $\left.{ }^{6} 1\right)$ a group of horticultural export companies, 2 ) designers of public policies, 3 ) research and development institutions, 4) educational institutions fostering human resources, 5) financial institutions, 6) suppliers, 7) agroindustrial enterprises, and 8) clients. Therefore, the core of the cluster is a group of companies in the same economic activity and located in the same region. This condition, as already mentioned, is fulfilled in Sinaloa. However, the following point should be highlighted.

The literature on industrial clusters gives a central role to small and medium enterprises, which make up the core of the cluster. Individually, such enterprises could not successfully compete in global markets but can when they are integrated in a cluster. Historical experiences have provided the basis for the modern theories about clusters, related to success stories of small and medium enterprises, For example, in the Italian cases, which are frequently mentioned, a combination of competition and cooperation among the companies takes place.

This aspect should be considered when analyzing Sinaloa. Though it is true that, when the area was founded, which covers a wide span of 50 to 100 years, many companies that today play a leading role in the horticultural market began as small and medium enterprises, today the situation is very different. Elizalde, a specialist for the Committee for Research and Defense of Vegetables (CIDH), pointed out that about 3,000 horticultural enterprises operate in Sinaloa. ${ }^{7}$ The smaller companies are located in the southern area. Among these firms, 110 or 120 own parcels of land parcels larger than 35 hectares and produce for the export market. Only 75 horticultural companies are registered by Bancomext as exporters in Sinaloa, because the bank considers only areas larger than 50 hectares. In the 2008-09 agricultural seasons, about 120 growers-exporters planted 47.624 hectares; this represents an average of 396 hectares per unit. The value of the exports in this cycle was USD 725 million. Thus, the average grower exported about USD 6 million of vegetables, which indicates that the export of vegetables in Sinaloa is not in hands of small businesses. ${ }^{8}$ These statistics point to an aspect that other scholars have not been considered: namely, the relevance of the market structure and its impact on the type of competition that develops among participants in a given market. More specifically, the domination of the market by large firms discourages the establishment of cooperative relations between firms. If the firms were small and therefore unable to access foreign markets unless they collaborated, they would cooperate. In fact, the largest horticultural companies operating in Sinaloa are not only large by global standards but also have the most advanced technology according to

\footnotetext{
${ }^{6}$ I have constructed this structure following Bajo's [14] review of the literature about clusters.

${ }^{7}$ Personal information from interview at December $11^{\text {th }}, 2009$.

${ }^{8}$ I wish to thank Raymundo Elizalde, a CIDH expert, for bringing this
} important point to my attention. international standards (see Fig. 4). In other words, these firms do not need to collaborate with each other. In Sinaloa, unlike Spain, there is no growers' cooperative, since most are so big and economically powerful that they do not need partners to share the costs of packaging, marketing, etc. On the contrary, each company has its own facilities, and sometimes companies rent facilities to smaller growers. These facts make clear that the export horticulture in Sinaloa is dominated by large companies.

This issue compels us to introduce a new element into the discussion on clusters. A cluster requires not only the presence of a large number of companies engaged in the same activity, but also they are small or medium; therefore, they need to cooperate to access international markets. This does not mean that once a cluster is established that its companies cannot grow and increase their scale of operations. In fact, this may be one of the objectives of the cluster. However, if the companies are of significantly different sizes, then the first condition for the formation of a cluster is absent.

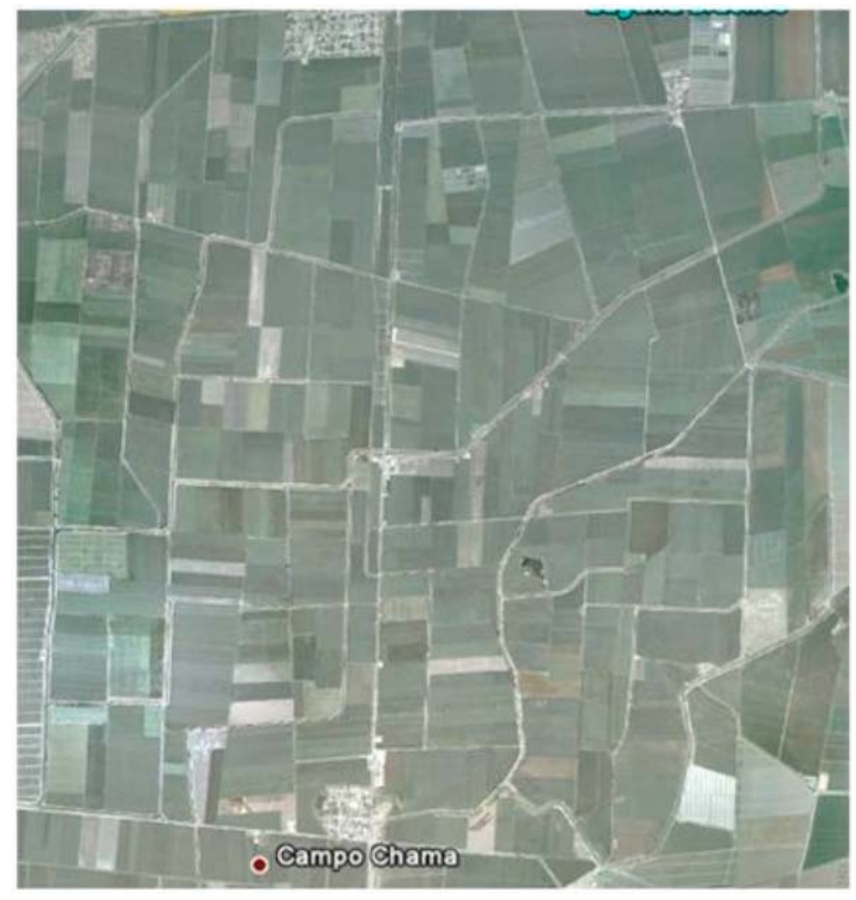

Fig. (4). Horticultural fields in the Valley of Culiacán. Source: Google Earth.

The next key element is a set of public institutions that design policies conducive to the formation of a cluster. Successful clusters, as well as projects for new clusters, reveal that the different levels of government (local, regional, national) play a central role $[16,17]$. In the case of Sinaloa, both the state and national governments led to a large-scale horticulture sector in the state through the creation of the required hydraulic infrastructure. There are currently 11 dams in Sinaloa; most were built in the second

${ }^{9}$ Carrillo [15] presents data from a survey of 40 horticultural companies located in the Valley of Culiacan, classified by size according to the number of persons employed, and the results show that only 2 companies are small (5\% of the sample), 18 are medium (45\%), and 20 are large (50\%). In addition, the growers that are not exporters are SMEs, while large and medium growers are exporters. 
half of the 20th century. However, there is a big lag in other infrastructure items, specially, an obsolete railroad operating in poor conditions and bad highways, particularly during the rainy season. More serious is the fact that, since the introduction of a neoliberal economic policy in Mexico, in the early 1980s, the Mexican state has given the market the leading role in the economy. However, horticulture growers never benefited directly from government subsidies that benefited producers of basic grains such as corn for years. Similarly, state enterprises, for example, Fertimex, provided fertilizer to Mexican farmers at low prices. Yet most of the fertilizers used by growers were not produced by Fertimex. All these facts point to a large gap in the realm of public policies.

The third component of a cluster is the research and development institutions. Most studies of successful clusters highlight the presence and active participation of educational institutions such as universities where research is carried out closely related to the economic activities of the cluster's core enterprises. Bajo [14], through a survey carried out in 2007 and early 2008, examined 25 exporting horticultural companies located in Sinaloa (15 in the center of the state, 7 in the north, and 3 in the south), out of 75 companies registered by Bancomext. Of the main innovations adopted by these companies, $75 \%$ came from abroad, $15 \%$ from within Mexico, and 10\% were developed by the company itself. Sixty-five percent of the companies interviewed acknowledged that they had completed innovations that had been initiated by institutions of higher education in Sinaloa. Concerning the university-industry collaboration, the majority (75\%) of the companies surveyed said that they had not signed any agreements with the institutions. In addition, the government's involvement in the innovation processes is very minimal. Only $20 \%$ of respondents said that the level of government involvement was acceptable, without saying that it was positive. The rest of the respondents stated that such participation was nil, low, or intermediate. The study concluded that the horticultural enterprises in Sinaloa do not give much credit to the government and educational institutions for promoting, supporting, and driving innovation development ([14] p. 20).

Therefore, the third element of a cluster, in the case of Sinaloa, is absent or so minimal that the component's role has no meaning in the development of horticulture.

However, in horticulture, the research core is genetics applied to the production of improved seeds that produce fruits with long shelf life and resistance to pests. This research is performed by a small group of large transnational companies located in developed countries, among which Aventis, BASF, Bayer, Dow AgroSciences, DuPont, FMC, Monsanto, and Syngenta are the most relevant. Some of these companies or their subsidiaries, such as Zeraim, Rogers, and USAgriseeds, have plants in Culiacan. These plants test seeds that have been developed by the companies' geneticists in Israel, the U.S., or Europe. In Mexico, for legal reasons, companies cannot produce seeds. The production of organic seeds may be allowed in the future, and Mexican growers could perhaps take advantage of this possibility, but for now, Mexican horticulture and certainly that in Sinaloa, depend significantly on research conducted by foreign companies. In the case of tomatoes, the main vegetable exported from Mexico and Sinaloa, the most important seed companies in the market are Zeraim Gedera, Syngenta Seeds/Rogers, Enza Zaden, Harris Moran, De Ruiter Seeds/Monsanto Seed Molina, Western Seed/Monsanto, Seminis/Monsanto, Sakata Seed.

The next component of the cluster is the presence of human resource training institutions, whose students should be trained appropriately for the activities of the core companies of the cluster. In Sinaloa, there are two institutions whose graduates are closely related to horticulture. The first is the Faculty of Agronomy of the Universidad Autonoma de Sinaloa, and the other one is the CIAD (Research Center for Food and Development). Furthermore, graduates of other specialties and college could support the horticultural business activities identified, such as biologists, business managers, and others. However, employers believe that students who graduate from the Sinaloan colleges do not master the required knowledge. Moreover, links between university and industry that could serve to reach improved understanding of the requirements of the horticultural companies are absent. Therefore, although there is a foundation for good cooperation between the sectors, this foundation has not developed for reasons that would be impossible to discuss in this paper. In sum, we conclude that the fourth component of the cluster is present but is still extremely weak.

The fifth component involves financial institutions supporting the cluster's activities. This role can be played by public institutions and governments at various levels (local, state, national) or by private companies such as banks or clients of the grower-exporters, or even by the horticultural enterprises themselves. Sinaloa's experience was analyzed in detail by Zazueta [18], who pointed out that the state's share of agriculture of the GDP is not commensurate with the commercial bank credit that has been extended to this sector and even shows a downward trend. For example, in 1995, $23.2 \%$ of the total registered credit went to agriculture, but in 2004, dropped to $19.7 \%$ ([18] p. 126). Medina [19] estimated a lower figure, since in 2004 only $6 \%$ of the loans made by commercial banks in Sinaloa were devoted to agriculture. The absence of institutional credit to the sector has been exacerbated since the imposition of neoliberalism in Mexico in the mid-1980s, as one of its principles has been to force companies to be competitive and allow the market to take crucial decisions based on the performance of the economic agents. Although loans to the manufacturing industry were also very small in $1995(9.35 \%)$, they were still lower at the end of the period $(5.61 \%)$. This indicates weak support for horticultural activities, and even less for the industry, which, of course, includes the food processing industry, a component of the analyzed cluster.

In the absence of credit from the government or commercial banks, horticultural growers have two options. In the case of large and consolidated companies, one option is to turn to self-financing. The other option, adopted most often in Sinaloa since the beginning of horticultural export activities about 100 years ago, is to use the credit provided by the trading companies to buy products. A survey of a sample of 40 companies in Sinaloa conducted by Carrillo [15] confirmed this situation and showed that the most important source of financings are U.S. distributors (42\%), 
followed by self-financing (32.5\%) and bank financing (20\%). Thus, we conclude that institutional credit as the fifth component of the cluster in Sinaloa is absent or very weak.

The sixth component of the cluster that is mentioned in the literature is common suppliers of inputs and services. The most important inputs and services for the horticultural sector are seeds, agrochemicals, specialized machinery, and greenhouses (which are becoming increasingly important).

Seeds are imported, and the largest transnational corporations, the seed producers, have offices or distributors in Sinaloa. The following is a list of the most important suppliers among them: ${ }^{10}$ Corona Seed Inc., Danson Seed Company, Inc., D. Palmer Seed Co., De Ruiter Seed Inc., Enza Zaden, Erma Zaden U.S.A., Euro Semillas de México (Rijk Zwaan), Genezis Seed, King Seeds y Cía., S.A. de C.V., LSL Plantscience LLC Molina Seed, S.A. de C.V. (distributor for NASCO, Wisconsin), Sakata Seed de México, S.A. de C.V., Ochoa Seeds (distributor for other companies), Orsetti Seed Company, Inc., US Agriseeds Inc de México, S.A. de C.V., Premium Seeds (integrated to Harris Moran), Golden Valley Seed, Asgrow, Peto Seed, and Bionova.

Speaking of agrochemicals, according to the Mexican Association of Fitosanitary Industry's (AMIFAC [20]) 2008 annual report, twelve firms engaged heavily and routinely in research activities for the manufacture of pesticides: Arysta Lifescience Mexico (Japan), BASF Mexicana (Germany), Bayer Cropscience (Germany), Cheminova Agro (Spain), Dow Agrosciences (U.S.), Dupont Mexico (U.S.), FMC Agroquimica de Mexico (U.S.), Koor Intercomercial (Israel), Monsanto (U.S.), Polaquimia (Mexico), Syngenta Agro (Switzerland), Valent de Mexico (subsidiary of Sumitomo, Japan).

With one exception, these companies are multinational corporations whose parent companies are located in developed countries. Moreover, many of these companies, directly or through subsidiaries, are also involved in producing improved seeds. To complement the activities of these large companies, another twenty-two companies are dedicated to the assembly, distribution, and marketing of plant protection products, and eighteen companies are dedicated exclusively to the distribution and marketing of phytosanitary products. There are numerous Mexican companies in the third group ([20] p. 5).

As far as the specialized machinery used in horticulture, in Mexico, there is no any national industry; this industry is dominated by foreign brands, whose products are distributed by their subsidiaries or by Mexican companies, all of them with offices in Sinaloa. Such is the case of John Deere, Massey Ferguson, Sumitomo, Komatsu, McCormick, and Yto, to mention some of the best known.

Finally, protected agriculture is not yet very extensive in Sinaloa but is expanding. In 1999-the 2000 cycle, there were only 82 hectares under this system, and in the 2008-2009 cycle, there were 2,873 hectares. Forty-six percent of this land grew different species of tomatoes [21]. In this case, the technology used comes from several countries, including Spain, Israel, France, and U.S. Even some Mexican

\footnotetext{
${ }^{10}$ Personal information from CIDH.
}

companies are beginning to participate in this activity. Of course, all these companies have offices or representatives in Sinaloa.

As noted above, the sixth component of the cluster has a strong presence in Sinaloa, but this component is external. This is relevant from the perspective of territorial and regional development, because it indicates that technology is not being created in the territory. Technology, as traditional in Mexico, is basically acquired from abroad. Therefore, this component is a highly relevant factor for the formation of the cluster and makes it heavily dependent on foreign companies.

The seventh element in the formation of an agroindustrial cluster is the presence of a group of companies responsible for the industrial processing of horticultural products. To discuss this point, we have to analyze the food industry in Sinaloa.

Several authors have highlighted the historical weakness of Sinaloa's industrial sector and its tiny contribution to the state's GDP and the national industrial product. Authors have also stressed the failed attempts to boost Sinaloa's industrialization promoted by the state governments before the '70s. The attempts were short-lived and had null results. In the '70s, the state government seriously pushed industrialization, but it did not result in the expected response from employers. In the 1980s, new attempts were made but they were not very functional. The government initiatives in the early ' 90 s primarily involved the installation of maquiladoras in Sinaloa, ${ }^{11}$ but the policies were insufficient and inefficient. Each new state government sets different priorities.

In this context of frustrated industrialization are located the food processing companies, which constitute the major part of Sinaloa's industrial sector. Although 2,301 companies in the food and beverage industry are currently registered, only 23 process and package fruits and vegetables. These companies' products are mainly tomato paste, dried tomatoes, mango pulp, hot sauce, canned or frozen vegetables, and dried chilies. Although, on average, these establishments employ 62 people, some are smaller, such as FES, Inc., with 30 permanent and 18 temporary employees, and some larger, as Alimentos del Fuerte, SA de $\mathrm{CV}$, with 1,060 permanent employees and 500 temporary workers. Other important companies are Conservas La Costeña and Industrias Guacamaya (information directly provided by the Department of Agribusiness of the State Government of Sinaloa). ${ }^{12}$ However, the industry of which these companies are a part makes a minimal contribution to the GDP of the state, around 5\%, while the agricultural sector accounts for $13.4 \%$ (data for 2007). In particular, the industrial production value is less than half the value of horticultural production and only about $37 \%$ of the value of horticultural exports (Data from Sinaloa's State Government 2009 and calculations based on data from CIDH).

\footnotetext{
${ }^{11}$ Maquiladora is an assembly plant which may import materials and equipment on a duty-free and tariff-free basis for assembly or manufacturing and then "re-exports" the assembled or manufactured product; sometimes back to the originating country.

${ }^{12}$ I must express my thanks to Ing. Diego Monjardin for his valuable support.
} 
To identify changes in Sinaloa's food industry, the results of 180 surveys conducted by Espinoza involving entrepreneurs in this sector are very useful. ${ }^{13}$ Although in the 1970s companies began to be established in this industry, almost half of the respondents (44.9\%) began operations in the 1990 s and $24.5 \%$ a decade earlier. Therefore, $69.4 \%$ of the surveyed companies started operations in adverse conditions because of the crisis in Mexico. These companies were created in response to a federal government economic policy along with a state policy, whose aim was to create jobs outside the traditional sectors in Sinaloa's economy (agriculture and fisheries). However, these companies are characterized by reduced diversity and little integration with other industries and have maintained a low participation in Sinaloa's GDP, by far lower than the participation in the national food industry in the national GDP. Moreover, even this low participation has tended to decrease.

Other characteristics of the establishments in the food industry are their low-tech and high-labor intensity, their small scale (mostly micro and small enterprises), and the strong geographic concentration: $55.6 \%$ are in Culiacan, $16.1 \%$ are in Los Mochis, $14.4 \%$ are in Mazatlan, $10.6 \%$ are in Guasave, and $13.3 \%$ are in El Rosario. ${ }^{14}$

An important point is the fact that, among the companies surveyed by Espinoza, only $1.7 \%$ was involved in tomato processing, while the majority was engaged in the manufacture of wheat flour (and its derivatives), meat, corn, or seafood.

Another relevant issue is the social origin of the interviewed entrepreneurs. Almost half (43.1\%) declared that their parents were tradesmen, $18 \%$ were descended from employees, and $14.4 \%$ from farmers. The others came from families of farmers, laborers, or fishermen. Thus, only $9 \%$ came from families of industrial entrepreneurs. Concerning the background of the interviewed entrepreneurs, the responses were as follows: $30.8 \%$ were tradesmen, $22.7 \%$ were employees, $5.8 \%$ were farmers, $3.5 \%$ were livestock farmers, $2.3 \%$ were bankers, and only $16.3 \%$ were industrial entrepreneurs. Accordingly, the industrial tradition is weak in Sinaloa, and most are merchants and others who are not known for their propensity for risk, innovation, in short, part of what is a modern industrial entrepreneur. This phenomenon is relevant because it may be one explanation for the lack of industrial entrepreneurship in Sinaloa. And four decades after the birth of the food processing industry in Sinaloa, the industry's current weakness has been recognized by the Council for the Development of Sinaloa (CODESIN), an organization composed of businessmen, citizens, and public officials, created in 1996 to contribute to the economic development of the state. According to Medina [19], director of Economic Studies of CODESIN, there is still no integration of the primary sector (agriculture) with the manufacturing sector, and the food industry in Sinaloa has very weak development. In addition, Sinaloa faces competition from other states in Mexico with significant industrial food production. Therefore, Sinaloa ranks 12th

\footnotetext{
${ }^{13}$ See Appendix 1.

${ }^{14}$ In addition, CODESIN [19] points out the strong geographic concentration of the food industry in Sinaloa; $90.3 \%$ of the establishments of this industry are concentrated in just three municipalities: Culiacán, Mazatlán, and Ahome.
}

(out of 32 states) in the national food industry. With $1.9 \%$ of the economic companies of the sector in the country, Sinaloa's contribution to the added value is just $2.3 \%$. Furthermore, data for 1994-2004 show that three quarters of Sinaloa's primary production have no added value.

Therefore, we conclude that the weight of the poorly diversified food industry in the state is far below its capacity and that the linkage between the primary and secondary sectors is far from its potential. A diversified and competitive food industry has not developed in Sinaloa. The seventh component of an agro-industrial cluster is absent in Sinaloa. ${ }^{15}$

A final component of the cluster is the presence of a common client group, which may well be located in the territory of the cluster or outside it. ${ }^{16}$ In this case, the direct customers of the growers in Sinaloa are companies located in Nogales, Arizona. The indirect final clients would include a wide range of buyers, mainly located in the eastern U.S., but not limited to that region. In this case, the key to the operation of Sinaloa's export horticulture is the concentration of trading companies at the border point closest to the producing region. Thus, the last factor for a cluster is present in the studied case; in addition, this last factor is crucial for Sinaloa. Actually, the companies located in Nogales, Arizona, allow export horticulture to exist in Sinaloa. The trading companies have provided loans to growers, but the companies' fundamental role has been to introduce products from Sinaloa to the U.S. market. However, the history of relations between trading companies and producers has not been without friction. This led some horticultural companies with financial capacity to establish their own trading companies in the U.S. to distribute their products. ${ }^{17}$

\section{SINALOA'S RESPONSE TO GLOBAL STANDARDS}

An analysis of the horticultural cluster in Sinaloa would be incomplete without considering how the cluster has responded to the demands imposed by global standards. We will refer briefly to two. One relates to the social conditions of agricultural workers, and the other concerns the environmental effects of horticulture on the territory. From the perspective of regional and territorial development, the formation of clusters should contribute to the general welfare of the population located in the territory of the cluster. One of the segments of the population particularly relevant for society is the workforce, which is also essential for the performance of horticultural activities.

In Sinaloa, harvesting activities (cutting and gathering) of the fruits are traditionally performed by migrant workers. Every year during the harvest season, usually in the autumn and winter months, about 300,000 people come to Sinaloa from the south of the country, particularly from Oaxaca,

\footnotetext{
${ }^{15}$ For this reason, some scholars prefer to speak, referring to Sinaloa, not of an agro-industrial district (cluster) but of an agro-commercial district (Carrillo [15]). However, the introduction of this concept takes into account only the absence of the industrialization of horticultural products, but it does not explain the absence of other factors that are taken into account here. ${ }^{16}$ It is also worth noting that most of Sinaloa's exports are concentrated on a small number of products. This is clearly a week point, because the diversification of exports is a crucial element in the world competition [23].

${ }^{17}$ For further details about trading companies in Nogales, Arizona, see López [24].
} 
Guerrero, and Chiapas, but sometimes also from Veracruz and Zacatecas. Most migrant workers live in extreme poverty, which forces them every year to leave their hometowns, where living conditions are becoming worse. The workers hope to find better labor conditions in Sinaloa's horticultural fields. Migrant workers often bring their wives and children, who also work very hard in the fields.

The issue of migrant workers' living conditions has been widely discussed, and there is no consensus. From the standpoint of international nongovernmental organizations (NGOs), this is a case of human rights violations. However, entrepreneurs have different points of views. Some think that the conditions offered to workers are fair and that the wages are sufficient. In fact, work and living conditions vary great among companies. It should be noted that the payment mechanism is usually piecework payment. Therefore, workers try to harvest as much fruit as possible, incorporating the entire family in these activities, including 10 - and 12-year-old children. This explains why workers insist on being allowed to work with their children. In contrast, some employers that are socially committed maintain that if the wage is sufficient, then the workers do not need their children's help, and they can attend school. In each field, therefore, there must be a school. The truth is that the conditions, quality, and efficiency of the schools vary widely from company to company, and the same can be said concerning teachers.

Thus, it is impossible to say that all Sinaloa's horticultural companies provide their workers with decent working and living conditions. Of course, there are some outstanding exceptions, but they only confirm the magnitude of the problem. ${ }^{18}$

Closely related to the previous point are the direct injury of agricultural workers and the indirect injury of all the population, due to careless use of water and abuse of agrochemicals and toxic substances in horticultural activities. $^{19}$

On the topic of water research, Diaz [30, 31], contrary to the optimistic views of those who regard Sinaloa as a territory rich in natural resources and suppose that its 11 rivers and many dams are a guarantee of endless abundance, warns of the imminent exhaustion of the state's natural resources. This author emphasizes that Sinaloa's water poverty is the result of 100 years of intensive agriculture, which has exported as much as possible of Sinaloa's horticulture to the United States market. Diaz maintains that Sinaloa has been exporting not just vegetables but also water to the United States. Certainly, Sinaloan growers have successfully managed to make inroads in the global market, but this success has been possible thanks to the water resources, currently in danger of collapse. Furthermore, stressing the systemic nature of economic and social processes, Diaz links the abuse and misuse of the precious liquid with the deterioration of other activities, such as fishing, as well as climatic changes. At the same time, many

\footnotetext{
${ }^{18}$ The literature on this issue is very large. As examples, see Grammont and Lara [25] and Posadas [26]. Also interesting is the evaluation of the Programa de Atención de Jornaleros Agrícolas coordinated by Yúnez-Naude [27]. About children working, see Sanchez [28].

${ }^{19}$ See the illustrative video of Halkin [29].
}

other factors have negative environmental effects. Among these factors are the industrialization of agriculture, the automobile culture and its consequences for urban life, the chaos of cities, and many others. The effects in Sinaloa are, among others, colder winters and hotter summers, and droughts alternating with off-season storms. Under these circumstances, little or nothing significant has been done by the various levels of government. No environmental policy exists in Sinaloa, while reality is continuously moving toward the destruction of the very sources of life.

With respect to environmental degradation caused by the misuse of agrochemicals and strongly toxic substances such as pesticides it has been demonstrated that a great number of pesticides banned in other countries are still used in Mexico. ${ }^{20}$ In addition, organophosphate pesticide residues have been detected in Sinaloa's soil and water, while traces of organochlorine pesticides have been identified in the blood of farm workers. Likewise, there is evidence of prolonged exposure of workers to organophosphorus pesticides, which are harmful to humans' health.

The above-mentioned indicates that some practices associated with export horticulture in Sinaloa are not contributing to the welfare of the inhabitants of the territory and are damaging the ecosystem. This is worrying if we remember that the purpose of the formation of clusters is the economic and social development of their territories; this means first, the welfare of the people and quality of their environment.

In short, when speaking of clusters, one must speak of territory; therefore, it would be wrong to forget the adverse ecological effects of horticulture as it has been practiced in Sinaloa. If we add the social component, characterized by the poor working conditions of migrant laborers and the frequent cases of child labor, then we have enough elements to qualify Sinaloa as a dysfunctional territory, a concept applied by Silva [32] to Andalusia.

The components and their discussion now leads to the task of characterizing the type of cluster that can be found in Sinaloa, the cluster's degree of progress, and the cluster's particular features, according to the conceptual framework developed in the following pages.

\section{TYPOLOGY OF CLUSTERS BY CONNECTIVITY AND DYNAMICS}

The idea behind the cluster concept is that if the different sectors of the economy of a locality or region are connected, then this locality or region will have a successful economic performance. Sinaloa's economic performance used to be high, but since the 1980s, the state's economic performance has been remarkably low. According to Trujillo and Gaxiola [33], the low performance of Sinaloa's economy is mainly due to the poor performance of the state's agricultural sector, on which the meager industrial and the enormous services sector largely depend. In the '60s, the situation was very different: the agricultural sector was a driving force for the rest of Sinaloa's economic activities. However, since the trade liberalization, things changed significantly, and currently Sinaloa's agricultural sector has become a burden for the state's entire economy. If this interpretation is

\footnotetext{
${ }^{20}$ See Appendix 2.
} 
correct, then one might think that there are productive linkages as well as unproductive linkages. Therefore there are dynamic clusters, based on productive linkages, as well as stagnant clusters, based on unproductive linkages. If this idea is correct, then Sinaloa's poor performance in the past two decades could be explained by the presence of a stagnant cluster. It is also necessary to investigate to what extent this cluster is complete or not and whether some linkages do not exist or are too weak.

A cluster could be interpreted as incomplete or truncated as follows. In Sinaloa, more precisely in Sinaloa's territory, there is an entrepreneurial web of low density, especially on the nodes that could invigorate the system (financial institutions and educational and research institutions) and, some nodes of high density act as a burden for territorial development, for example, the hypertrophied services sector. These arguments allow us to refine the concept of cluster, taking into account two dimensions. One is the cluster's level of connectivity, and the other is the cluster's degree of economic dynamism. Therefore, hypothetically we would have four types of clusters, as shown in the following diagram.

Let us first explain the meaning of these two dimensions (see Fig. 5).

The degree of a cluster's connectivity depends on the number and magnitude of interrelationships among the eight players included in a cluster. If any of these agents does not exist or exists but has a weak presence, namely, few links with the other players, then we have a situation of low connectivity. Conversely, if all players are present and they are strongly interrelated, then the cluster has high connectivity. Of course, many intermediate situations may occur, and it is important to emphasize that the connections between actors, to be considered strong, should not only exist but must also be channels for frequent transactions of high value.

On the other hand, a cluster may be more or less dynamic; it can remain stagnant or even show a clear decline. The criteria for evaluating the dynamism of the cluster should take into account the cluster's contribution to the real wealth of the territory and even of the country. Real wealth means not only the GDP but also the quality of life, both socially and environmentally speaking, produced by the cluster in its territory. Moreover, a dynamic cluster depends not only on regional factors but also on its more or less successful integration into global value chains and networks of global standards (see Messner [10]).

According to the proposed typology, we suggest the following interpretation of Sinaloa's current horticultural cluster.

Since the mid-1980s, when the neoliberal paradigm was put into effect in Mexico, with an emphasis on trade liberalization, minimization of state interventionism, privatization, deregulation, and prioritization of market mechanisms for allocating resources, Sinaloa's economy, whose axis remains export horticulture, has shown a tendency toward stagnation. To explain this phenomenon, since we are talking about an economy strongly integrated in the globalized world particularly by way of NAFTA (the
North America Free Trade Agreement), it is necessary to take into account that, as pointed out by Messner ([10]), the local sites and regions are integrated in global value chains and confront a world of global standards (technical, social, environmental standards) established by companies, NGOs, consumers, governments, and other organizations and institutions. Thus, the cluster concept relates to the localregional dimension and is related to systemic competitiveness, which stems from interactive relationships between companies and their institutional environment. However, the experience we have studied here shows that the dynamics of a territory, Sinaloa in this case, cannot be explained only by the presence or absence of a cluster. On the one hand, for cluster analysis, one must consider the two aforementioned dimensions: connectivity and economic dynamism. The degree of connectivity can be explained by the behavior of agents in the local area, which may be either local (governments, companies, institutions) or external (large multinational companies in industries such as chemicals and machinery). The degree of the dynamism of the cluster is due to intra-regional and global factors. In particular, the position of the cluster position in the global value chains in terms of governance, market access, and type of regional economic structure to which the cluster belongs is extremely relevant.

On the other hand, since a cluster is located in a territory and its study becomes relevant for the impact the cluster may have on developing the territory, which includes economic factors and social and environmental issues, an evaluation of the performance of a cluster in territorial terms must take into account the cluster's social and environmental effects.

Considering all these facts, from the perspective of the welfare of the territory, Sinaloa's horticultural cluster is incomplete and stagnant. It is incomplete because important players are missing, their presence is imperceptible, or their links with other actors in the cluster are weak or nonexistent. The cluster is stagnant because its impact on Sinaloa's economy has not been strong enough to make other sectors of the economy achieve growth rates above the national average or higher than those reached by Sinaloa in better times. This stagnation is expressed equally in the decreasing contributions of Sinaloa's different economic sectors to the national economy as well as in the loss of competitiveness of the state's main export products in their markets.

In addition, the social and environmental dysfunctionality of some practices linked to horticultural activities must be considered. Speaking of dysfunctionalities, two phenomena that are not derived directly from the horticulture are related to Sinaloa's poor economic performance as a whole must be discussed. These phenomena are also dysfunctional from the perspective of the territory. I am speaking of migration, which is causing Sinaloa's demographic decline, namely, the so-called human capital loss, and, very important, drug trafficking. This illegal activity has become an option for many inhabitants in Sinaloa who have no other viable employment alternatives in the formal economy. Of course, drug trafficking has a deep negative impact in terms of social values and coexistence. Fear and insecurity in Sinaloa are destroying the social tissue, which is the vital essence of the territory. 


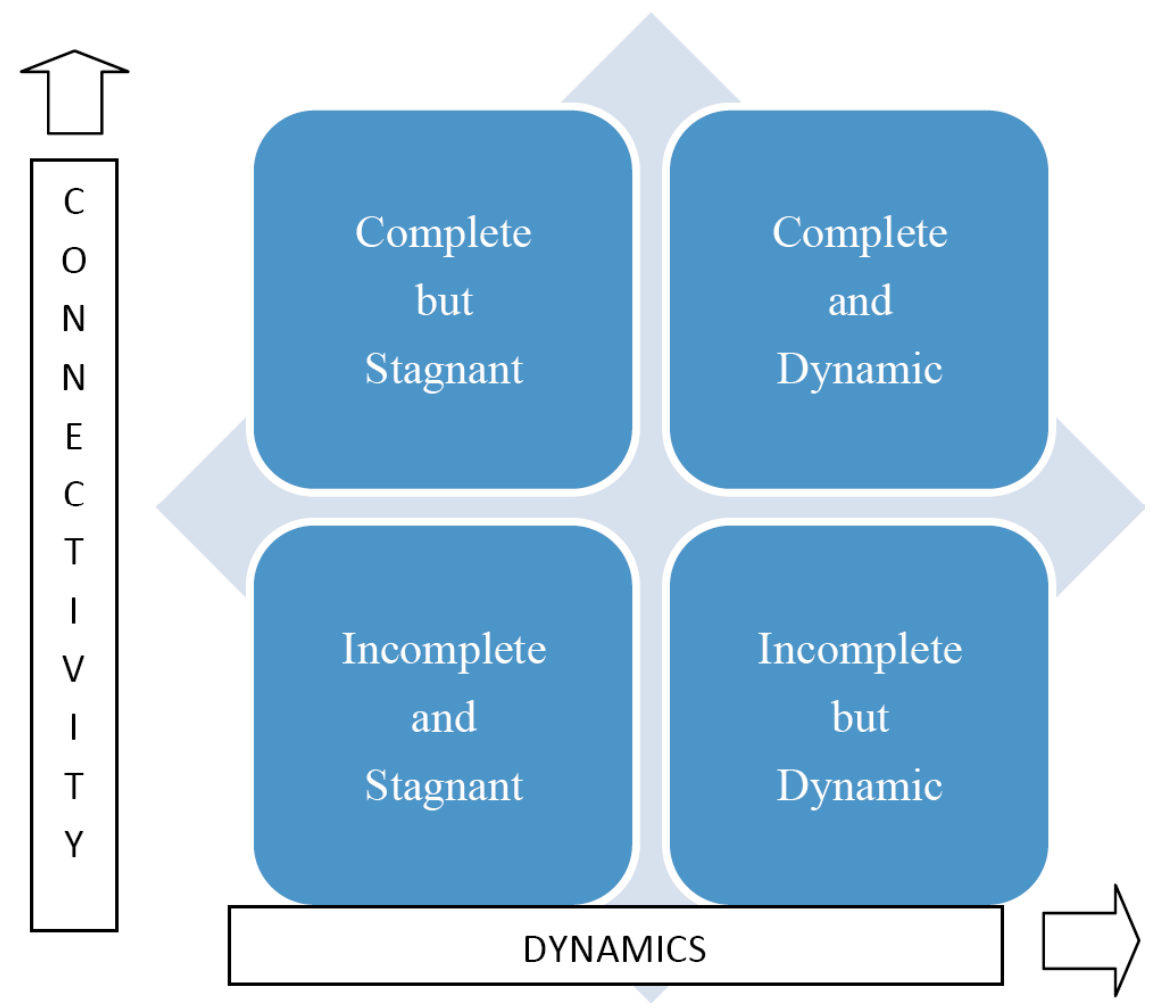

Fig. (5). Typology of clusters.

These remarks make clear that the problems associated with the existence of a cluster in Sinaloa go beyond purely economic phenomena, both concerning their origins as with respect to their social impact and the solutions to such problems. Finally, from a territorial perspective, Sinaloa's situation could be depicted by several concepts. One of these is modern enclave, used by Macias [34]. Another one is peripheral territory applied by Delgado [35] to the case of Andalusia. Useful, too, is the concept of dysfunctional territory used by Silva [32] for the Andalusian case. All these concepts refer essentially the same problem and could probably be used interchangeably. Personally, I prefer to use the concept of disembedded territory because it takes up the tradition of Karl Polanyi and allows us to insert the interpretation of the studied phenomena into a context not only economic but also political, social, and global. I use here the concept disembedded in a double sense. On the one hand it refers to the horticulture as economic activity without enough forward and backward linkages to develop the whole economy of Sinaloa. On the other hand it describes the territory of Sinaloa whose economy is mainly centered on the horticulture, but the rest of productive activities of this territory are weakly connected with the horticulture. Moreover, our study makes clear the inadequacy of a theoretical approach focused only on the cluster to explain the economic performance of a region. In Sinaloa, there are certainly missing elements to complete the formation of a cluster, but it should be asked if Sinaloa's performance would be better if these items were given. In that case, Sinaloa's systemic competitiveness would probably increase, but we must also take into account the other two vertices of the world economic triangle [10], namely, Sinaloa's position in the horticulture global value chains and the area's ability to adapt to demands imposed by global standards.
In terms of the first of the elements described above, Sinaloa is inserted into the global value chain of horticulture in one of the initial links (nodes), namely, the production and, to some extent, the distribution of fresh vegetables and fruits. Therefore, the governance in this chain is not in the hands of the grower-exporters but is exerted mainly by other agents: the American distribution and trading companies that transport the goods to big consumption centers and, increasingly relevant, the powerful supermarket chains, which are becoming major customers of fruits and vegetables. Nowadays, these customers are imposing their own rules on the rest of agents of the value chain. Sinaloa's growers' subordinate position would be probably not be modified if the local cluster was perfectly articulated; then, they are offering goods of low added value in the market. Therefore, growers receive only a fraction of the final price of their products. This is also explained by the subordinate role of agriculture in the modern global economy, which is dominated by manufacturing activities and high-value-added services.

With respect to the second element mentioned above, the pressures from the world of global standards are increasingly strong. In this case in particular, pressures related to food safety are increasing significantly. These pressures will continue regardless of the degree of articulation of the elements of Sinaloa's cluster. Moreover, current sanitary and phytosanitary barriers are being imposed on horticultural trade flows, not only on Sinaloa but everywhere in the world. That is why the cluster concept leads us to the field of the systemic competitiveness of the territory, but no further. To evaluate Sinaloa's performance as a territory in the global economy, regional analysis focused on the formation of 
clusters must be enriched with an analysis of global value chains and global standards.

The outcomes of the present research point to the lack of an agro-industrial cluster centered on Sinaloa's export horticulture, although it is noteworthy that important efforts have been made, especially by the growers themselves, toward the construction of such cluster. These efforts, however, have been insufficient in the absence of other impulses that should come from all levels of government (municipal governments, state government, national government), as well as from higher education institutions located in Sinaloa. Their task is promoting research and development (R\&D) and fostering human resources, not only highly qualified but also qualified in the fields of science and technology relevant to horticultural producers.

Moreover, Sinaloa's horticultural sector is embedded in the global economic crisis and is dominated by a small number of transnational corporations in key horticultural activities such as the production of improved seeds, agrochemicals, and cultivation technology (fertirrigation, greenhouses, etc.). It is impossible for domestic firms to successfully compete with these corporations.

Another element is provided by the dismantling of the manufacturing industry in Sinaloa. Thus, productive linkages that would add value to horticultural products are not present, and the few companies dedicated to the preservation and processing of fruits and vegetables located in Sinaloa are an exception that confirms the critical situation. Finally, in Sinaloa, unlike other historical experiences where clusters are formed based on small and medium producers, the market structure is characterized by a clear preponderance of large companies. Therefore, in some cases, each of these large companies, thanks to the scale and diversity of operations, including packaging, transporting, and distributing horticultural products, becomes a center of gravity for other smaller units, but without real integration at the regional level, not to mention homogeneity among producers due to large size differences. In Sinaloa, it is impossible to speak, as in cases of other countries (for instance Almería in Spain), of a socio-institutional network that integrates most of the players involved in a production system, such as local and regional administrations, several entrepreneurial associations, research centers, universities, etc. ${ }^{21}$

The outcomes of this research indicate that there is no agro-industrial system, district, or cluster in Sinaloa. Some scholars (Carrillo [15], Aguilar and Frias [40], Frias [41], Lopez and Aguilar [42]) admit this fact, but they insist on the existence of some kind of district or cluster. Therefore, they have adopted from Caldentey [36] the concept of the agrocommercial district or cluster. However, they do not see that the real problem is not just the absence of food industrial plants but the absence or weakness of other actors as well as the lack of socio-institutional networks to support the whole system. That is why for Sinaloa it seems suitable to apply the

\footnotetext{
${ }^{21}$ About the important experience of Andalucía, whose similarities to as well as differences with Sinaloa are of great interest, see the pioneering studies of Caldentey [36] and the very extensive study by Ferraro [37]. Aznar [38] introduces competition from Morocco as a new element. For a social perspective, see Delgado [35, 39] and Silva [32], who clearly explains the different interpretations of other scholars.
}

term productive specialization area used by Silva [32] in her study on Andalusia. In addition, the environmental dysfunctions stressed by Silva with regard to this region of Spain can be applied to Sinaloa. The same applies in relation to the lag between economic dynamism and territorial development, which makes evident limitations, mistakes, confusion, and the lack of coordination among different administrative levels of government and, finally, the remarkable fact that agents and institutions pay more attention to the economic subsystem, disregarding the environmental, social and territorial dimensions of the development (Silva [32] p. 35-36).

Finally, I will try to provide an explanation of the studied phenomena.

\section{CAUSES OF AN INCOMPLETE AND STAGNANT CLUSTER IN A DISEMBEDDED TERRITORY: SINALOA}

To consolidate their position in the U.S. market, Sinaloa's growers have made great efforts, and their achievements are undeniable. For example, a group of the leading farmers in Sinaloa created Agroindustrias Del Norte, founded in 1969, which purchased the American Niagara Chemical Company to produce and distribute agricultural inputs for Sinaloa's growers. The company later expanded its coverage to other cities in Mexico, and in 2002, Agroindustrias Del Norte decided to expand its activities. Based on strategic alliances with domestic and foreign firms, the company created two new divisions: fertilizers and cardboard. At the same time, Agroindustrias Del Norte is a distributor for large multinational companies such as Bayer, Cropsciences, Syngenta, Dow AgroSciences, Du Pont, Buckman, BASF, FMC, Arvesta, Monsanto, and others. Another remarkable achievement has been, as already mentioned, the establishment, by the producers themselves, of trading companies in the United States. The creation in 1932 of the largest and most influential grower's organization of the country, the Confederation of Agricultural Associations of Sinaloa (CADES), was especially important. However, the growers still suffer several weaknesses, such as the concentration of their attention on just the productive aspects of the horticulture, neglecting the business organization and the coordination of the companies, management practices and sales strategies, postharvest handling, and transportation of goods to the United States [43]. At the same time, from a historical perspective, there is an evident contrast between Sinaloa's prosperity from 1960 to the 1980 s, when the state led regional development, and the drastic fall from the '90s. Sinaloa currently ranks among the lowest states of the country in terms of economic growth and the capacity to generate employment opportunities. These lags are explained by Lopez [44] as follows. Sinaloa's economic expansion was characterized by strong federal public investment policies that, under the influence of the Green Revolution, made the area a major supplier of food and raw materials for the domestic market, and a leading exporter of agricultural and sea products. However, changes in the orientation of the growth model, which occurred during the 1980s, deeply affected Sinaloa, blocking its agriculture and destroying the limited industrial development. Sinaloa has undergone major changes in its economic structure, namely, contraction of the 
primary sector (agriculture), a disproportionate expansion of the service sector, and a stagnating industrial sector. All these phenomena are closely associated with failed public policies. The performance of the agricultural sector has been disappointing; however, this is not enough to explain the trends in Sinaloa's economy. In fact, the industrial and service sectors were and continue to be highly inefficient. On the other hand, the agricultural sector has not been able to compensate for such inefficiencies, mainly because the agriculture was seriously damaged and could not produce an economic surplus to invest in other sectors [33].

Before the opening up of the Mexican economy, Sinaloa lacked an industrial basis beyond the food industry, and the federal government covered the transportation costs of agricultural raw materials to the major markets in the country. The economic liberalization transformed such costs in critical points and allowed Sinaloa's disadvantages to flourish. This new situation made any further industrial development impossible and hurt Sinaloa's competitiveness in food production, since no investments were made in infrastructure, which were necessary to improve the state's communication with the rest of the country and the United States.

One more aspect, related to corporate behavior, should be added. Farmers in Sinaloa know how to manage modern technology and are willing to adopt new technologies, making the necessary investments. Notwithstanding this, agriculture, and particularly horticulture, is a risky activity. This issue helps to foster a kind of individualistic mentality. Moreover, high earnings and high losses are always possible. This contributes to promote a certain mentality of a gambler. These two factors are unsuitable for building cooperative associations and alliances among enterprises, which could be an advantage for penetration into larger markets. These factors are also inadequate for the transfer of agricultural capital into the industry, which has more stable trends, fluctuations of lesser magnitude, but also longer waiting times to build and obtain high profits.

If it is true, that by the 1970 s, there was already a local productive system [15], and even an agro-business district [41], built on a dense entrepreneurial web whose axis was export horticulture, and if this system was also involved in numerous industrial and service activities linked to agriculture, what happened in the following decades remains to be explained. How such trends provoked disruptions and involutions that damaged such achievements and led to the current situation, characterized by a still-strong export horticulture industry suffering from a weakening process, a disappearing industry, and a gigantic and inefficient service sector, must be investigated.

This story has yet to be written, and we can only point out some hypotheses as explanations, summarizing the arguments presented throughout this paper. One is the unilateral trade liberalization of the Mexican economy as Mexico became a member of GATT in 1986 and a member of NAFTA in 1994 is one explanation. Two, the bad debt crisis in Mexican agriculture following the 1995 crisis and the virtual disappearance of the agricultural development bank could also be causes. Since 1994, credit to the agricultural sector from commercial banks and development banks has been dramatically reduced, at an annual rate of -
$16.3 \%$. Even in the current decade, agricultural nonperforming loans (NPLs) remain considerably high. Three, structural reforms (1982-1988) involved the adjustment of public finances, financial market liberalization, trade liberalization, privatization of public enterprises, deregulation, and reduced government intervention in the economy in general and agriculture in particular. Four, in the absence of a national policy to promote research for the creation of improved seeds, growers depend on the large transnational corporations that dominate the world market. Moreover, these multinational corporations (MNCs), thanks to trade liberalization, have better access to the Mexican market. Five, due to the opening up of trade, the MNCs in the agricultural equipment industry (John Deere, Massey Ferguson, Caterpillar, Komatsu, and others) enjoy better conditions for establishing their brands in Mexico. Six, the formation of any type of cluster is not an automatic outcome of the market. Instead, as several historical experiences show, the presence of the state as the promoter and organizer of initiatives aimed at the formation of such clusters is necessary and even unavoidable. The main purpose of such clusters is not increasing the profitability of individual companies but promoting regional development, where the correct mixture of sectoral, local, and national public policies is fundamental.

Finally, there remains only to emphasize the need to analyze the experience of export horticulture in Sinaloa from a broad perspective, considering the local momentum, as well as the global dynamics, incorporating in the analysis economic, social, political, and cultural factors. This is the only way to better understand our reality and to forge the necessary tools for the construction of a better future.

\section{ACKNOWLEDGEMENTS}

The work of this paper has been supported by Universidad Autónoma de Sinaloa (Profapi 2009/113), Consejo Estatal de Ciencia y Tecnología del Estado de Sinaloa, and Promep-Sep.

\section{APPENDIX 1}

Espinoza JA. Perfil de la industria alimentaria de Sinaloa. In: López et al. Los sistemas regionales de innovación. Un acercamiento al caso de Sinaloa. Culiacán (Sinaloa, México): Universidad Autónoma de Sinaloa 2002; pp. 229-282.

This is a survey applied to 180 food industry enterprises located in Sinaloa and performed during 1999. The outcomes correspond to a broader research project at the Science Center of Sinaloa which included about six members. The document is available only in Spanish and it is important because there are few or none studies about this sector in Sinaloa. The figures mentioned in this article are taken from the study of Espinoza. Some years later López [22] published the findings of a similar research about the manufacturing industry in Sinaloa, not just the food industry. His findings confirm those of Espinoza.

\section{APPENDIX 2}

The most recent and complete study about this issue is:

Beraud JL, Galindo JG, Covantes C, Eds. Jornaleros y medio ambiente: los agroquímicos en la agricultura horsinaloense. Culiacán (México): Universidad Autónoma de Sinaloa 2008. 
The figures mentioned in my article were taken from this study, which is only available in Spanish, but the interested reader can contact the authors: jose_beloz@hotmail.com, jlberaud@yahoo.com.mx.

\section{REFERENCES}

[1] Mares DR. Penetrating the International market: theoretical considerations and a Mexican case. New York: Columbia University Press 1987.

[2] INEGI. El sector alimentario en México. Edición, 2008. Available from: http://www.inegi.org.mx/prod_serv/contenidos/espanol/bvin egi/productos/integracion/sociodemografico/SAM/2008/sam2008.p df

[3] Dávila A. Los clusters industriales del noreste de México (19932003). Perspectivas de desarrollo en el marco de una mayor integración económica con Texas. Región y Sociedad 2008; 10(41): $57-88$

[4] Maya CJ, Cabada A. Free trade and fresh vegetables exports: the experience of Sinaloa, Mexico. In: Onishi T, Cheng B, Eds. The shape of the East Asian economy to come. Lonely rethoric or global reality. Newcastle: Cambridge Scholars Publishing 2007; pp. 78-96.

[5] Gaxiola HE, Trujillo JD. Los ajustes en la agricultura de Sinaloa. In: Maya CJ, Ponce YC, Eds. Apertura comercial y (sub)desarrollo regional. La experiencia de Sinaloa. México: Plaza y Valdés 2010; pp. 49-71.

[6] OECD. Policy Brief. Available from: http://www.oecd.org/dataoe cd/34/22/38653705.pdf. [cited: May 2007].

[7] Ketels C. The development of the cluster concept-present experiences and further developments, 2003. Available from: http://www. isc.hbs.edu/pdf/Frontiers_of_Cluster_Research_2003.11.23.pdf.

[8] Mandang T, Hardjanto W. Development of Agro Industrial Cluster (AIC) in Indonesia. An investment opportunity. Available from: http://kdei-taipei.org/artikel/investasi/Agroindustrial_Cluster.pdf.

[9] OECD. Innovative Clusters. Drivers of national innovation systems, enterprise, industry and services. Paris: OECD Publications 2001.

[10] Messner D. The concept of the "World Economic Triangle". Global governance patterns and options for regions. IDS Working Paper No. 173. Brighton: Institute of Development Studies 2002.

[11] INEGI. Síntesis de resultados. II Conteo de población y vivienda 2005. Aguascalientes (México). Available from: www.inegi.org.mx

[12] INEGI. Gobierno del Estado de Sinaloa, Anuario Estadístico de Sinaloa 2009, Aguascalientes, 2009.

[13] Gobierno del Estado de Sinaloa. Quinto informe del gobernador Jesús Aguilar Padilla. Culiacán, Sinaloa, 2009. Available from: http://www.sinaloa.gob.mx.

[14] Bajo A. La vinculación como componente estratégico en la formación de clúster en las regiones del estado de Sinaloa, desde una perspectiva de la economía del conocimiento. Congreso Iberoamericano: Ciudadanía y Políticas Públicas en Ciencia y Tecnología. Madrid, Spain. February 5-8, 2008. Available from: http://www.oei.es/CongresoCiudadania/comunicaciones.htm

[15] Carrillo A. Articulación productiva de empresas y productores hortícolas en el valle de Culiacán: la situación actual en perspectiva histórica. In: Romero ME, Carrillo A, Eds. Empresa y agricultura comercial en el Noroeste de México. Historia económica y tendencias actuales. México: Universidad Nacional Autónoma de México 2009; pp. 375-419.

[16] Casaburi G. Dynamic agroindustrial clusters: the political economy of competitive sectors in Argentina and Chile. London: Macmillan Press 1999.

[17] Surinach J, Moreno R, Vaya E, Eds. Knowledge externalities, innovation clusters and regional development. Northampton: Edward Elgar Publishing 2007.

[18] Zazueta A. La banca y el financiamiento al sector agropecuario en Sinaloa 1995-2004. MS [Thesis in Regional Economics]. Universidad Autónoma de Sinaloa 2006.

[19] Medina E. El sector de alimentos en Sinaloa. El reto de consolidar el liderazgo. Consejo para el Desarrollo Económico de Sinaloa. Unidad de Estudios Económicos. Culiacán (México), 2006. Available from: http://s3.esoft.com.mx/esofthands/include/upload_ files/18/Archivos/Sector\%20de\%20Alimentos\%20en\%20Sinaloa.p df.
[20] Asociación Mexicana de la Industria Fitosanitaria, A.C., Informe Anual 2008, México, 2008. Véase también la página electrónica de la asociación en: www.amifac.org.mx.

[21] Comisión para Investigación y Defensa de las Hortalizas (CIDH). Cierre de ciclo de hortalizas 2008-2009. Culiacán, Sinaloa. 2009; Available from: http://www.cidh.org.mx [cited: $7^{\text {th }}$ Feb 2010].

[22] López S. Empresarios e innovación tecnológica en Sinaloa. Región y Sociedad 2003; 15(27): 179-214. Available from: http://redalyc.u aemex.mx/redalyc/pdf/102/10202706.pdf.

[23] Agosin, M. Export diversification and growth in emerging economies. CEPAL Rev 2009; 97: 115-31.

[24] López LM. La gobernancia de las distribuidoras en la cadena hortícola de valor Sinaloa-Estados Unidos. PhD Thesis in Economics. Universidad Autónoma de Sinaloa (México) 2008.

[25] Grammont HC, Lara S. Encuesta a hogares de jornaleros migrantes en regiones hortícolas de México: Sinaloa, Sonora, Baja California y Jalisco. México: Universidad Nacional Autónoma de MéxicoInstituto de Investigaciones Sociales 2004.

[26] Posadas F. Agricultural laborers in Mexico and the United States. Rural sociological society: annual meeting. Manchester: New Hampshire, July 28, 2008. Available from: http://www.allacademi c.com/meta/p254804_index.html

[27] Yúnez-Naude A. Evaluación externa del programa de atención de jornaleros agrícolas. México: El Colegio de México/Secretaría de Desarrollo Social del Gobierno de México 2005. Available from: http://precesam.colmex.mx.

[28] Sánchez K. Los niños en la migración familiar de jornaleros agrícolas. In: Del Río N, ed. La infancia vulnerable de México en un mundo globalizado. México: Universidad Autónoma Metropolitana/UNICEF 2000; pp. 79-94.

[29] Halkin A. Migrar o Morir: jornaleros agrícolas en los campos tóxicos de Sinaloa, 2008. Available from: http://www.youtube. com/watch?v=WLI5eRZNkmw

[30] Díaz R. Los límites locales del crecimiento. Sinaloa en la dimensión global. Culiacán (Sinaloa): Universidad Autónoma de Sinaloa 2004.

[31] Díaz R. Sinaloa: la escasez de agua y la variabilidad climática. In: Maya C, Aguilar O, Eds. Sinaloa en la Globalización. Costos ecoló-gicos, sociales y económicos. México: Plaza y Valdés 2007; pp. 71-101.

[32] Silva R. Redes socio-institucionales, dinámica innovadora y disfunciones territoriales en los sistemas agrocomerciales andaluces. Revista de Estudios Regionales 2004; 70: 13-40.

[33] Trujillo JD, Gaxiola HE. Economía y agricultura en Sinaloa. In: Maya CJ, Ponce YC, Eds. Apertura comercial y (sub)desarrollo regional. La experiencia de Sinaloa. México: Plaza y Valdés 2010; pp. 19-47.

[34] Macías A. Empresarios y dinámicas extraterritoriales en la agricultura de hortalizas en México. El caso Sayula, Jalisco. In Maya CJ, Hernández MC, Eds. Globalización y sistemas agroalimentarios. México: Juan Pablos Editor 2010; pp. 125-54.

[35] Delgado M. Andalucía en la otra cara de la globalización. Una economía extractiva en la división territorial del trabajo. Sevilla (España): Megablum 2002.

[36] Caldentey P. El distrito agro-comercial del campo de Dalías (España). Agroalimentaria 1998; 7: 21-8.

[37] Ferraro FJ, Ed. El sistema productivo almeriense y los condicionamientos hidrológicos. Madrid: Caja Rural de Adlmería, Civitas Ediciones 2000.

[38] Aznar JA. La competencia entre la horticultura intensiva de Marruecos y España. Cizur Menor (España): Cajamar, Thomson Civitas 2006

[39] Delgado M, Gavira L. Agricultura y trabajo rural en la globalización. Revista Española de Estudios Agrosociales y Pesqueros 2006; 211: 21-61.

[40] Aguilar G, Frías E, Eds. Historias de empresarios y grupos de poder en Sinaloa: del porfiriato al salinismo. México: Juan Pablos 2009.

[41] Frías E. La exportación del tomate sinaloense y su valor comercial: 1920-1956. In: Romero ME, Carrillo A, Eds. Empresa y agricultura comercial en el Noroeste de México. Historia económica y tendencias actuales. México: Universidad Nacional Autónoma de México 2009; pp. 107-41.

[42] López MJ, Aguilar G. La trayectoria empresarial y la creación de empresas en el sistema productivo local del Valle de Culiacán, 1948-1970. El caso de cinco familias. In: Aguilar G, Frías E, Eds. 
Historias de empresarios y grupos de poder en Sinaloa: del porfiriato al salinismo. México: Juan Pablos 2009; pp. 123-62.

[43] Gaxiola HE. Sinaloa: tecnología, agua y competitividad en su horticultura. In: Maya CJ, Aguilar O, Eds. Sinaloa en la globalización. Costos ecológicos, sociales y económicos. México: Plaza y Valdés 2007; pp. 197-228.
[44] López G. El contexto económico del desarrollo rural de Sinaloa 1994-2005. In: Maya CJ, Aguilar O, Eds. Sinaloa en la globalización. Costos ecológicos, sociales y económicos. México: Plaza y Valdés 2007; pp. 45-70.

Received: February 19, 2010

(C) Carlos J. Maya-Ambía; Licensee Bentham Open.

This is an open access article licensed under the terms of the Creative Commons Attribution Non-Commercial License (http://creativecommons.org/licenses/by$\mathrm{nc} / 3.0 /$ ) which permits unrestricted, non-commercial use, distribution and reproduction in any medium, provided the work is properly cited. 